\title{
Comparison of Modified Tessier and Revised BCR Sequential Extraction Procedures for the Fractionation of Heavy Metals in Malachite Ore Samples Using ICP-OES
}

Elif Varhan Oral

Dicle University, Faculty of Pharmacy, Department of Analytical Chemistry, 21280 Diyarbakır, Turkey

\section{INTRODUCTION}

Heavy metals are dangerous environmental pollutants and their toxicity is an increasing problem for ecological, evolutionary, nutritional, and environmental reasons (1). The accumulation of heavy metals in soil and waters depends on anthropogenic activities and lithogenic sources and are found to alter the geochemical distribution of heavy metals more than in lithogenic sources (2-4). Mining activities facilitate the movement and distribution of heavy metals, and according to World Health Organization (WHO) reports, it is one of the activities that can affect human health and pollute the environment (5). Contamination of the environment with potentially hazardous materials is a complex function due to factors such as hydrology, geology, geochemistry, mining, and ore processing (6). Metal mining is known to cause contamination by spreading heavy metals into the environment in excess concentrations to soil and water $(7,8)$. Therefore, analysis of heavy metals in the structure of ores is of great importance.

Information about the presence of heavy metals in solids, such as soil and ore, can be obtained not only from the total concentration but also by assessing their specific chemical forms, their binding states, and their elemental properties (9). Potentially toxic elements can accumulate between different

\footnotetext{
*Corresponding autbor.

E-mail:evarban@dicle.edu.tr

Tel: +90 $4122488030 / 7543$

Fax: +90 5056893699:
}

\begin{abstract}
In this study, two sequential extraction procedures (modified Tessier procedure and revised BCR procedure) were applied for the decomposition of $\mathrm{Fe}, \mathrm{Cu}$, $\mathrm{Co}, \mathrm{Pb}, \mathrm{Zn}$, and $\mathrm{Mn}$ in the structure of malachite ore from the Keban region of Turkey. The effects and efficiency of each extraction step used in these procedures were examined. Metals analysis was performed by ICP-OES. Due to the differences in the binding forms of the metals existing in the structure of the ore and the different properties of reagents used, the concentrations of the metals were different in the extraction steps of both procedures. When the results were examined, it was found that the metal concentrations passing to the solution in each extraction step of the modified Tessier procedure were much higher than of the revised BCR procedure. Thus, it was concluded that the modified Tessier procedure is more suitable for decomposing metals in malachite ore.
\end{abstract}

phases such as water-soluble, exchangeable, carbonate-associated, Fe-Mn oxide-associated, organicassociated, and residual forms (10, 11). Therefore, when evaluating the toxic properties of trace elements in solids, determination of the total metal content provides insufficient information about bioavailability, mobility, or toxic effects $(9,12)$. As a result, information about the bonding force between the metals and the ore and the capacity of mobilization of heavy metals existing in the ore structure is necessary.

Sequential extraction procedures provide information on potential bioavailability, mobility of solid and metal bonds, and heavy metal bioavailability $(11,13)$. Among various and different sequential extraction procedures, the most commonly used procedures are the Tessier method and its modifications (14-20) and the Community Bureau of Reference (BCR) method and its modifications (19-28).

The five-step sequential extraction procedure was first introduced by Tessier et al. (18) and many studies have utilizied this procedure since $(17,19)$. This five-step scheme has grouped the metals as exchangeable, weakly absorbed, hydrous oxide-bound, organic bound, and lattice material components (29-32). The modified Tessier procedure, which is another extensively utilized sequential extraction method, differs from the original Tessier method by having a four-step extraction: exchangeable, carbonates, organic matter and sulfides, and residual (19). The BCR procedure and the Tessier method greatly resemble each other, except there is a major difference in the first step of the BCR method. In the study of Ure et al. $(28,30,32)$, the exchangeable and carbonate-bound steps were combined in the first part, not calculating them separately. Hence, this study proposed a three-step sequential extraction procedure and they divided the metals into acid-soluble/exchangeable, reducible, and oxidizable fractions (19, 29). 
The purpose of the current study is to compare the concentration of metals in the malachite ore structure obtained from the Keban region by applying the modified Tessier and the revised BCR procedures. For the heavy metal fractions, the extraction steps and the aforementioned methods were tested.

\section{EXPERIMENTAL}

\section{Instrumentation}

An Optima ${ }^{\mathrm{TM}} 2100 \mathrm{DV}$ inductively coupled plasma optical emission spectrometer (ICP-OES) (PerkinElmer, Inc., Shelton, CT, USA) was used for the metals analysis. The respective instrumental operating parameters are listed in Table I. The absorbance was measured at the maximum wavelength of $238.2 \mathrm{~nm}$ for Fe, $228.6 \mathrm{~nm}$ for $\mathrm{Co}, 257.6 \mathrm{~nm}$ for $\mathrm{Mn}, 327.4 \mathrm{~nm}$ for $\mathrm{Cu}, 220.4 \mathrm{~nm}$ for $\mathrm{Pb}$, and $206.2 \mathrm{~nm}$ for $\mathrm{Zn}$.

TABLE I

ICP-OES Instrumental Operating Conditions

\begin{tabular}{|c|c|}
\hline \\
\hline \multicolumn{2}{|l|}{ Parameters } \\
\hline Plasma gas flow rate & $15 \mathrm{~L} \mathrm{~min}^{-1}$ \\
\hline Auxiliary gas flow rate & $0.2 \mathrm{~L} \mathrm{~min}^{-1}$ \\
\hline Nebulizer gas flow rate & $0.8 \mathrm{~L} \mathrm{~min}^{-1}$ \\
\hline Sample flow rate & $1.5 \mathrm{~L} \mathrm{~min}^{-1}$ \\
\hline View mode & Axial \\
\hline Read & Peak area \\
\hline Source equilibration time & $15 \mathrm{~s}$ \\
\hline Read delay & $50 \mathrm{~s}$ \\
\hline Replicates & 3 \\
\hline Purge gas & Nitrogen \\
\hline Shear gas & Air \\
\hline Plasma gas & Argon \\
\hline Maximum & Wavelength \\
\hline $\mathrm{Fe}$ & $238.2 \mathrm{~nm}$ \\
\hline Co & $228.6 \mathrm{~nm}$ \\
\hline Mn & $257.6 \mathrm{~nm}$ \\
\hline $\mathrm{Cu}$ & $327.4 \mathrm{~nm}$ \\
\hline $\mathrm{Pb}$ & $220.4 \mathrm{~nm}$ \\
\hline $\mathrm{Zn}$ & $206.2 \mathrm{~nm}$ \\
\hline
\end{tabular}

Acid digestion of the samples was performed using a MWS-3 microwave digestion system (Berghof Co., Germany) with pressure control. A Memmert brand shaker (Memmert GmbH, KG, Germany) and a Heraeus brand Labofuge-200 model centrifuge (Thermo Fischer Scientific, Germany) were utilizied for the sequential extractions. The $\mathrm{pH}$ measurements and adjustments were carried out with a Mettler-Toledo pH meter (Schwerzenbach, Zürich, Switzerland). A Baysan brand jaw crusher and pulverizer (Turkey) was used for grinding the ore which was then passed through a 100 mesh sieve (Yüksel Kaya Makina, standard testing sieve, Turkey). A Milli-Q ${ }^{\circledR}$ purifier system (Millipore Corporation, USA) was used for obtaining ultrapure water.

\section{Chemicals and Standard Solutions}

All reagents used in this study were of analytical grade: hydrogen peroxide (Merck), acetic acid (Sigma), ammonium acetate (Merck), hydroxylamonium hyrochloride (Sigma), magnesium chloride, sodium acetate, hydrofluoric acid and nitric acid (Fluka). Serial dilution of the $1000 \mathrm{mg} \mathrm{L}^{-1}$ stock solution of the desired element was done in preparation of the standard solutions.

\section{Preparation of Ore Samples}

In this study, the ore samples were obtained from the Keban

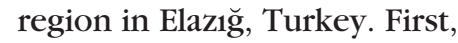
the samples were stored in boxes, then dried in an oven at $120^{\circ} \mathrm{C}$ for 2 hours andy broken with the jaw crusher and pulverizer, and finally milled and passed through a sieve of 100 mesh.

\section{MATERIALS AND METHODS}

\section{Sequential Extraction Procedure}

In this study, the heavy metal concentrations in malachite ore

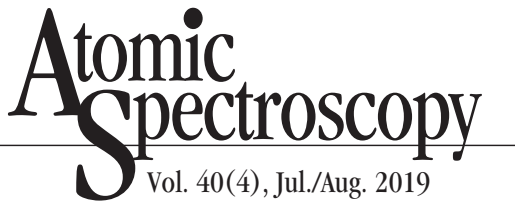

were calculated by using the modified Tessier and revised BCR procedures, and the data obtained from these two procedures were compared. The chemicals used in the sequential extraction procedures and the extraction conditions are listed in Tables II and III. After the extraction steps, the ore samples were washed with ultrapure water, and the supernatants separated by centrifugation. The reason for this step was to eliminate the remaining chemical residues from the previous extraction steps.

\section{Revised BCR Procedure}

The revised BCR is a 3-step sequential extraction procedure which has been proposed by gathering and validating the fractionation methods used for soils and solids (33). The original BCR procedure can also be applied to solids such as soils (34) and sediments (35). Compared with the original BCR procedure, the revised BCR procedure was studied using a high concentration of $\mathrm{NH}_{2} \mathrm{OH}-\mathrm{HCl}$ and low $\mathrm{pH}$ (33). In this procedure, approximately $1 \mathrm{~g}$ of the ore sample was weighed and metal extraction was carried out by adding the specified volume and concentrations of chemicals listed in Table II. The mixtures obtained after each step were centrifuged and separated from the residue. The first step of this method depends on acetic acid extraction, the second step is a hydroxylamine hydrochloride extraction, and the third step is an hydrogen peroxide oxidation and ammonium acetate extraction. In step four, the residual phase is extracted using aqua regia $\left(\mathrm{HCl} / \mathrm{HNO}_{3}, 3: 1\right)$. After this step, the resulting mixture was filtered through a filter paper and completed to $100 \mathrm{~mL}$ volume with ultrapure water (19).

\section{Modidfied Tessier Procedure}

Table III presents the modified Tessier procedure diagram. In 
step 1 , approximately $1 \mathrm{~g}$ of the ore sample is extracted with $10 \mathrm{M} 1 \mathrm{~mL}$ of ammonium acetate $(\mathrm{pH}=7)$. The mixture is then shaken at room temperature for 1 hour at $150 \mathrm{rpm}$ and centrifuged at $4,000 \mathrm{rpm}$ for 10 minutes. The aqueous phase is decanted and completed to $50 \mathrm{~mL}$ volume with ultrapure water. In step 2, $1 \mathrm{M}$ $10 \mathrm{~mL}$ of acetic acid is added to the residue obtained from step 1 . After shaking for 1 hour at $150 \mathrm{rpm}$, the mixture is centrifuged at $4,000 \mathrm{rpm}$ for 10 minutes. Then, the aqueous phase is decanted to $50 \mathrm{~mL}$ with ultrapure water. In step 3, $5 \mathrm{~mL}$ of $30 \% \mathrm{H}_{2} \mathrm{O}_{2}$ is added to the residue obtained from step 2 . The $\mathrm{pH}$ is adjusted to 2.00 with nitric acid; shaken at $150 \mathrm{rpm}$ at $35^{\circ} \mathrm{C}$ for 3 hours and centrifuged at 10,000 rpm, respectively. The sample is then filtered through a filter paper
(10 mesh size) and completed to $100 \mathrm{~mL}$ volume with ultrapure water. In step 4 , aqua regia $(2.5 \mathrm{~mL}$ $\mathrm{HNO}_{3}(65 \%)$ and $\left.7.5 \mathrm{~mL} \mathrm{HCl}(37 \%)\right)$ is added to the residue remaining from step 3; then solubilization is performed by microwave oven. The sample is then filtered through the filter paper, and finally completed to $100 \mathrm{~mL}$ volume with ultrapure water (19).

\section{RESULTS AND DISCUSSION}

\section{Revised BCR Procedure}

The first step was utilizied for determining the solubilization ratio of the metal ions ( $\mathrm{Fe}, \mathrm{Cu}, \mathrm{Zn}, \mathrm{Pb}$, and $\mathrm{Mn}$ ) in the ore structure by forming acetate salts. As a result of this step, it was thought that these ions in the ore structure could pass at different rates according to their solubility in the mineral structure; this observation was supported with the experimental results as listed in Table IV.

The second step was applied to create conditions where the metal ions can pass into the solution by reduction of the hydroxyl amine present in the medium and both the proton donor and the complexing properties of $\mathrm{HCl}$. When Table IV was examined, it was observed that the other metals $(\mathrm{Cu}, \mathrm{Zn}, \mathrm{Pb}$, $\mathrm{Mn}$ ), except for Fe, were dissolved, which may be due to the Fe precipitate as its hydroxide compounds.

The reason for the addition of $\mathrm{H}_{2} \mathrm{O}_{2}$ is that it provides decomposition of organic matter $\left(\mathrm{CO}_{2}, \mathrm{H}_{2} \mathrm{O}\right.$, $\mathrm{NO}_{\mathrm{x}}$ ) as a strong oxidant due to its high oxidizing activity which causes a reduction electrode potential of $1.70 \mathrm{~V}$. This step was done for dissolution of the sulfur compounds by producing elemental S

TABLE II

Operating Conditions of Revised BCR Sequential Extraction Procedure

\begin{tabular}{|c|c|c|c|}
\hline \multirow[t]{2}{*}{ Fraction } & \multirow[t]{2}{*}{ Extracting Agents } & \multicolumn{2}{|c|}{ Extraction Conditions } \\
\hline & & Shaking Time ${ }^{\mathrm{a}}$ & Temperature \\
\hline F1. Exchangeable + water and acid soluble & $40 \mathrm{~mL} \mathrm{CH}{ }_{3} \mathrm{COOH}(0.11 \mathrm{M}, \mathrm{pH}=7)$ & $16 \mathrm{~h}$ & $20^{\circ} \mathrm{C}$ \\
\hline F2. Iron and manganese oxides & $40 \mathrm{~mL} \mathrm{NH}{ }_{2} \mathrm{OH}-\mathrm{HCl}(0.5 \mathrm{M}, \mathrm{pH}=5)$ & $16 \mathrm{~h}$ & $20^{\circ} \mathrm{C}$ \\
\hline F3. Organic matter and sulfides & $\begin{array}{l}20 \mathrm{~mL} \mathrm{H}_{2} \mathrm{O}_{2}(30 \%, \mathrm{pH}=2) \text { and then } \\
50 \mathrm{~mL} \mathrm{CH}_{3} \mathrm{COONH}_{4}(1 \mathrm{M}, \mathrm{pH}=2)\end{array}$ & $1 \mathrm{~h}, 2 \mathrm{~h}, 16 \mathrm{~h}$ & $20,85,20^{\circ} \mathrm{C}$ \\
\hline F4. Residual & $\begin{array}{l}10 \mathrm{~mL} \text { demineralized water and } \\
10 \mathrm{~mL} \text { aqua regia }\left(\mathrm{HCl} / \mathrm{HNO}_{3}, 3: 1\right)\end{array}$ & $26 \mathrm{~min}$ & $\begin{array}{l}\text { Microwave } \\
\text { Oven }\end{array}$ \\
\hline
\end{tabular}

a Shaking was applied at $30 \mathrm{rpm}$.

TABLE III

Operating Conditions for Modified Tessier Sequential Extraction Procedure

\begin{tabular}{|c|c|c|c|}
\hline \multirow[t]{2}{*}{ Fraction } & \multirow[t]{2}{*}{ Extracting Agents } & \multicolumn{2}{|c|}{ Extraction Conditions } \\
\hline & & Shaking Time ${ }^{\mathrm{a}}$ & Temperature \\
\hline F1. Exchangeable & $10 \mathrm{~mL} \mathrm{NH}_{4} \mathrm{CH}_{3} \mathrm{COO}(1 \mathrm{M}, \mathrm{pH}=7)$ & $1 \mathrm{~h}$ & $20^{\circ} \mathrm{C}$ \\
\hline F2. Carbonates & $10 \mathrm{~mL} \mathrm{CH}_{3} \mathrm{COOH}(1 \mathrm{M}, \mathrm{pH}=5.5)$ & $1 \mathrm{~h}$ & $20^{\circ} \mathrm{C}$ \\
\hline F3. Organic matter and sulfides & $5 \mathrm{~mL} \mathrm{H}_{2} \mathrm{O}_{2}(30 \%, \mathrm{pH}=2)$ & $3 \mathrm{~h}$ & $35^{\circ} \mathrm{C}$ \\
\hline F4. Residual & $\begin{array}{l}10 \mathrm{~mL} \text { demineralized water and } \\
10 \mathrm{~mL} \text { aqua regia }\left(\mathrm{HCl} / \mathrm{HNO}_{3}, 3: 1\right)\end{array}$ & $26 \mathrm{~min}$ & $\begin{array}{l}\text { Microwave } \\
\text { Oven }\end{array}$ \\
\hline
\end{tabular}

${ }^{\text {a }}$ Shaking was applied at $150 \mathrm{rpm}$. 
and metal ions by converting them into the highest oxidation state. Because the $\mathrm{pH}$ of the medium is fixed at about 2.00, the acetate compounds of these metal compounds can dissolve and enter the aqueous medium. However, when the results of Table IV were examined, it seemed that the passage of these elements (except for Mn) to the solution is prevented because they can be converted to the highest oxidation steps by oxidizing them with $\mathrm{H}_{2} \mathrm{O}_{2}$. However, in this step only the determination of Mn can be interpreted as MnS which has passed into the aqueous medium since the solubility product is too high. The last step was applied to ensure passage of the ions into the mineral structure which cannot pass to the solution in the previous steps. After addition of half-diluted $\mathrm{HCl} / \mathrm{HNO}_{3}$ solution $(3: 1)$ into the residue, the mixture is put into a microwave oven where the ions pass into the solution.

\section{Modified Tessier Procedure}

The first step was carried out to determine the ions which can be passed to the solution by addition of $\mathrm{NH}_{4} \mathrm{CH}_{3} \mathrm{COO}$ and effective buffering at $\mathrm{pH}$ 7.00. As a result, the obtained values from this step are higher than $\mathrm{CH}_{3} \mathrm{COOH}$ addition and buffering at $\mathrm{pH} 7.00$.

In order to determine the presence of carbonated compounds in the structure, the $\mathrm{pH}$ of the $\mathrm{CH}_{3} \mathrm{COOH}$ medium was adjusted to 5.5, then solubilization was applied in step 2. When the results of Table IV were examined, it was observed that $\mathrm{Fe}, \mathrm{Cu}, \mathrm{Co}, \mathrm{Zn}, \mathrm{Pb}$, and $\mathrm{Mn}$ passed to the solution.

The addition of $\mathrm{H}_{2} \mathrm{O}_{2}$ causes the decomposition of organic matter $\left(\mathrm{CO}_{2}, \mathrm{H}_{2} \mathrm{O}, \mathrm{NO}_{\mathrm{x}}\right)$ since it is a strong oxidizer by having a reduction electrode potential of $1.70 \mathrm{~V}$ in the third step. The third step is applied to ensure the dissolution by producing elemental S from the sulfur compounds and converting the metal ions to their highest oxidation step. Since the $\mathrm{pH}$ of the medium is fixed at around 2.00 , it is thought that the metal ions present in this sample may dissolve and enter the aqueous medium. However, after examining the results in

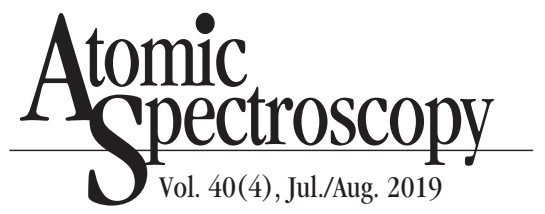

Table IV it can be seen that only Mn and $\mathrm{Cu}$ can be dissolved at the specified $\mathrm{pH}$ level in $\mathrm{H}_{2} \mathrm{O}_{2}$ medium, and the others cannot be converted to their highest oxidation steps.

The remaining ions in the ore structure after applying the previous procedures are dissolved in the fourth step. The aqua regia is added to the residue, then the solution is put into the microwave oven, and thereby it is expected that the remaining ions $(\mathrm{Fe}, \mathrm{Cu}, \mathrm{Co}$, $\mathrm{Pb}, \mathrm{Zn}$, and $\mathrm{Mn}$ ) are passed into solution. Our aim in implementing these resolution steps was to identify the possible ions in the sample.

\section{CONCLUSION}

The modified Tessier and the revised BCR procedures were examined to reveal the two main difference between the two procedures as: (a) The way in which metals bonded to the ore and (b) the characteristics of the reactants. Therefore, the amount of metals penetrating to the solution is different for both procedures. When the obtained results were compared, the $\mathrm{Fe}, \mathrm{Cu}, \mathrm{Pb}$ and $\mathrm{Mn}$ concentra-

TABLE IV

Results Obtained (mean \pm standard deviation, $n=3$ ) for Sequential Extraction Procedures

\begin{tabular}{lcccccc}
\hline Revised BCR & $\begin{array}{c}\mathrm{Fe} \\
\left(\mathrm{mg} \mathrm{kg}^{-1}\right)\end{array}$ & $\begin{array}{c}\mathrm{Cu} \\
\left(\mathrm{mg} \mathrm{kg}^{-1}\right)\end{array}$ & $\begin{array}{c}\mathrm{Co} \\
\left(\mathrm{mg} \mathrm{kg}^{-1}\right)\end{array}$ & $\begin{array}{c}\mathrm{Pb} \\
\left(\mathrm{mg} \mathrm{kg}^{-1}\right)\end{array}$ & $\begin{array}{c}\mathrm{Zn} \\
\left(\mathrm{mg} \mathrm{kg}^{-1}\right)\end{array}$ & $\begin{array}{c}\mathrm{Mn} \\
\left(\mathrm{mg} \mathrm{kg}^{-1}\right)\end{array}$ \\
\hline Step 1 & $6.10 \pm 0.15$ & $8186 \pm 175$ & $54 \pm 1$ & $2.24 \pm 0.05$ & $149 \pm 3$ & $289 \pm 6$ \\
Step 2 & $\mathrm{Nd}$ & $5024 \pm 122$ & $32.31 \pm 0.74$ & $0.42 \pm 0.01$ & $39.12 \pm 0.81$ & $194 \pm 4$ \\
Step 3 & $\mathrm{Nd}$ & $\mathrm{Nd}$ & $\mathrm{Nd}$ & $\mathrm{Nd}$ & $\mathrm{Nd}$ & $2.73 \pm 0.06$ \\
Step 4 & $224,400 \pm 5432$ & $5846 \pm 124$ & $82 \pm 3$ & $79 \pm 2$ & $574 \pm 15$ & $610 \pm 16$ \\
\hline Modified Tessier & \begin{tabular}{c}
$\mathrm{Fe}$ \\
\multicolumn{2}{c}{$\left.\mathrm{mg} \mathrm{kg}^{-1}\right)$}
\end{tabular} & $\begin{array}{c}\mathrm{Cu} \\
\left(\mathrm{mg} \mathrm{kg}^{-1}\right)\end{array}$ & $\begin{array}{c}\mathrm{Co} \\
\left(\mathrm{mg} \mathrm{kg}^{-1}\right)\end{array}$ & $\begin{array}{c}\left.\mathrm{Pb}^{-1}\right) \\
\left(\mathrm{mg} \mathrm{kg}^{-1}\right)\end{array}$ & $\begin{array}{c}\mathrm{Zn} \\
\left(\mathrm{mg} \mathrm{kg}^{-1}\right)\end{array}$ & $\begin{array}{c}\mathrm{Mn} \\
\left(\mathrm{mg} \mathrm{kg}^{-1}\right)\end{array}$ \\
\hline Step 1 & $17,215 \pm 510$ & $35,308 \pm 859$ & $67 \pm 2$ & $96 \pm 3$ & $170 \pm 4$ & $308 \pm 7$ \\
Step 2 & $343 \pm 9$ & $73,008 \pm 1690$ & $61 \pm 1$ & $35.73 \pm 0.72$ & $199 \pm 5$ & $193 \pm 5$ \\
Step 3 & $\mathrm{Nd}$ & $2.62 \pm 0.06$ & $\mathrm{Nd}$ & $\mathrm{Nd}$ & $\mathrm{Nd}$ & $47.22 \pm 1.15$ \\
Step 4 & $257,400 \pm 6748$ & $6794 \pm 138$ & $80 \pm 3$ & $123 \pm 2$ & $451 \pm 11$ & $637 \pm 18$ \\
\hline
\end{tabular}

Nd: Not detected. 
tions passing to the solution in each extraction step of the modified Tessier procedure were much higher than those of the revised BCR procedure. However, it was only in the fourth step of the BCR procedure when the Co and $\mathrm{Zn}$ concentrations passing to the solution were higher than of those in the modified Tessier procedure. It can, therefore, be stated that the modified Tessier procedure proved to be a more suitable procedure for the purposes of decomposing Fe, $\mathrm{Cu}, \mathrm{Co}, \mathrm{Pb}, \mathrm{Zn}$, and $\mathrm{Mn}$ in malachite ore. In addition, the modified Tessier procedure requires less chemicals and a shorter analysis time.

$\overline{\text { Received March 19, } 2019 .}$

\section{REFERENCES}

1. F. M. Hassan, M.M. Saleh, and J.M. Salman, Iraq. J. Chem. 7, 685 (2010).

2. A. Sargaonkar, and V. Deshpande, Environ. Monit. Assess. 89, 43 (2003).

3. M. Pérez-López, M.H. de Mendoza, A.L. Beceiro, and F.S. Rodríguez, Ecotox. Environ. Safe. 70, 154 (2008).

4. K.C. Beeson, W.R. Griffitts, and D.B. Milne, National Academy of Sciences, Washington, D.C., USA, 88 (1977).

5. R. Dabiri, M. Bakshi Mazdeh, and H. Mollai, J. Min. Environ. 8(2), 277 (2017).

6. M.M. Salvarredy-Aranguren, A. Probst, M. Roulet, and M.P. Isaure, Appl. Geochem. 23, 1299 (2008).

7. M. Anju and D.K. Banerjee, Chemosphere 78, 1393 (2010).

8. M. Anju and D.K. Banerjee, Environ. Monit. Assess. 176, 67 (2011).

9. K. Nemati, N.K., Abu Bakar, M.R. Abas, and E. Sobhanzadeh, J. Hazard. Mater. 192, 402 (2011).

10. B. Krasnodebska-Ostrega, J. Paldyna, J. Kowalska, L. Jedynak, and
J. Golimowski, J. Hazard. Mater. 167,128 ( 2009).

11. D.L. Lake, P.W.W. Kirk, and J.N. Lester, J. Environ. Qual. 13, 175 (1984).

12. M. Ghaedi, F. Ahmadi, and M. Soylak, J. Hazard. Mater. 147, 226 (2007).

13. M. Zemberyova, J. Bartekova, and I. Hagarova, Talanta 70, 973 (2006).

14. T.O. Ferreira, X.L. Otero, P.V. Torrado, and F. Macias, Soil Sci. Soc. Am. J. 71, 484 (2007).

15. T. Huynh, A.R. Tong, B. Singh, B. J. Kennedy, Clays Clay Miner. 51, 397 (2003).

16. E. Peltier, A.L. Dahl, and J.F. Gaillard, Environ. Sci. Technol. 39, 311 (2005).

17. W. Salomons and U. Forstner, Springer-Verlag, Berlin, Germany (1984).

18. A. Tessier, P.G.C. Campbell, and M. Bisson, Anal. Chem. 51, 844 (1979).

19. E.D. van Hullebusch, S. Utomo, M.H. Zandvoort, and P.N.L. Lens, Talanta 65, 549, (2005).

20. H. Yin, N. Tan, C. Liu, J. Wang, $X$. Liang, M. Qu, X. Feng, G. Qiu, W. Tan, and F. Liu, Chemosphere 161, 181 (2016).

21. N.T. Basta, J.A. Ryan, and R.L. Chaney, J. Environ. Qual. 34, 49 (2005).

22. D.T. Cuong, and J.P. Obbard, Appl. Geochem. 21, 1335 (2006).

23. S. Kartal, Z. Aydin, and S. Tokalioglu, J. Hazard. Mater. 132, 80 (2006).

24. M.D. Petit, and M.I. Rucandio, Anal. Chim. Acta 401, 283 (1999).

25. P. Quevauviller, Anal. Chem. 17, 289 ( 1998).

26. P. Quevauviller, G. Rauret, H. Muntau, A.M. Ure, R. Rubio, J.F. Lopez-Sanchez, H.D. Fiedler, and B. Griepink, Fresenius J. Anal. Chem. 349, 808 (1994).

27. G. Rauret, J.F. Lopez, A. Sahuquillo, R. Rubio, C. Davidson, A. Ure, and P. Quevauviller, J. Environ. Monit. 1, 57 (1999).
28. A.M. Ure, P. Quevauviller, H. Muntau, and B. Griepink, Int. J. Environ. Anal. Chem. 51, 135 (1993).

29. J.L. Gomez Ariza, I. Giraldez, D. Sanchez-Rodas, and E. Morales, The Science of the Total Environ. 271 (2000).

30. A.J. Zimmerman and D.C. Weindorf, Int. J. of Anal. Chem. 1 (2010).

31. I. Maiz, I. Arambarri, R. Garcia, E. Millan, Environ. Pollut. 110, 3 (2000).

32. A. Sherry, J. Faye, M. Richards, A.M. Gallardo, K.R. Campbell, and R. Sudowe, J. Radioanal. Nucl. Chem. 312, 37 (2017).

33. K.F. Mossop and C.M. Davidson, Anal. Chim. Acta 478, 111 (2003).

34. G. Rauret, J.F. Lopez-Sanchez, A. Sahuquillo, E. Barahona, M. Lachica, A.M. Ure, C.M. Davidson, A. Gomez, D. Luck, J. Bacon, M. Yli-Halla, H. Muntau, Ph. Quevauviller, J. Environ. Monit. 2, 228 (2000).

35. C.M. Davidson, R.P. Thomas, S.E. McVey, R. Perala, D. Littlejohn, A.M. Ure, Anal. Chim. Acta 291, 277 (1994). 